【論 文】

UDC : $72.01: 72.011 .2$
日本建築学会計画系論文報告集 第 411 号・1990 年 5 月 Journal of Archit. Plann. Environ. Engng, AIJ, No.411, May, 1990

\title{
『枕草子』における建築空間 \\ THE ARCHITECTURAL SPACE IN MAKURANOSOUSI
}

\author{
若山 滋* \\ Shigeru WAKAYAMA
}

We extract the words of architectural space from MAKURANOSOUSI, classify and concider them by architectural and contextual element.

In MAKURANOSOUSI, the space esthetics of the KOUKYUU womans in the HEIAN dynasty are expressed. And MAKURANOSOUSI is regarded as the original text of good taste in Japanese culture.

As the result of this analyzing, we collect architectural space in MAKURANOSOUSI as follows.

(1) KYUUTEI as a city of the theater

(2) TATEGU, KAGU, KURUMA as a stage setting

(3) esthetics of taste and circumstances

(4) emotion from "OKASI" to "AWARE"

Keywords : literature, theater, valuation

\section{序}

「春は，あけぼの。やうやう白くなりゆく山ぎは，すこしあ かりて，紫だちたる雲の，細くたなびきたる。

夏は，夜。月のころは，さらなり。闇もなほ。螢のおほく 飛びちがひたる，また，ただ一つ二つな゙，ほのかにうち光 りて行くも，をかし。雨など降るも，をかし。

秋は, 夕ぐれ。夕日のさして, 山のはいと近うなりたるに, 烏の, 寝どころへ行くとて，三つ四っ，二つ，三つなど，飛 びいそぐさへ，あはれなり。まいて，雁などの列ねたるが， いと小さく見ゆるは, いとをかし。日入りはてて, 風のおと, 虫の音など，はたいふべきにあらず。

冬は，つとめて。雪の降りたるは，いふべきにもあらす。 霜のいと白きも。またさらでもいと寒きに，火などいそぎお こして，ぬるくゆるびもてゆけば，火桶の火も，白き灰がち になりて,わろし。」(1)

『枕草子』は, 冒頭から, 春は朝がいい, 夏は夜がいい, というような, 季節による, 時と状況の評価であり，そ れも全く独断的にきめつけている。清少納言「枕草子】 には，全編にこの独断・評価の気分がみなぎっている。 「よし」「わろし」「をかし」「めでたし」「にくし」「わび し」「くちおし」「ゆかし」など，ありとあらゆる生活様 態の評価の書であるといってよく，その評価の基準は， 単なる個人的な趣味の感覚によっている。それは日本文 化における「趣味の良さ」の原典のようなもので，この とき既に，今日われわれが感じている「日本的趣味」と いうものの大筋は確立されたと思われる。もちろんそれ は, 平安王朝の後宮女性という, 極めて特異な存在によ
るものではあるが，特異であるからこそむしろ，その力 は広く長く後世にまで伝わりえたのではなかろうか。

さて文学は，それを読む人に何らかの心象風景を想起 させるものだが，その風景には自然空間とともに建築空 間が存在する。そこに表れる建築空間は現実そのものと いうより，作者の心に映じたものの言語化であり，虚構 としての文学に表現されたものは, 史実としての記録に 表現されたものとは質の異なるものである。つまり文学 の中の建築空間は, 一旦人間の情感のフィルターを通過 したものであって，そこにわれわれが読み取るものは， 建築そのものであるとともに，その時代，その文化の， .人間の建築空間に対する情感である。

本論の目的は，「枕草子」に表れる建築空間を調べる ことによって，この時代の人間の建築空間に対する情緒 性について考察するとともに，平安時代の建築空間に対 する人間の建築空間情緒といったものを, 読み取ろうと するものである。

\section{1.『枕草子』の位相と構造}

『枕草子」は，菅原道真によって遣唐使が廃止され (894 年), 古今和歌集」が編まれて（905 年）後の, 国風文化華やかなりし頃，一条天皇の中宮定子の女房， 清少納言による, 一種の随筆である。成立は 1000 年頃 とされるが，諸説ある。紫式部の「源氏物語』と並ぶ平 安王朝女流文学の代表であるが, この時代には, 多くの 日記随筆文学, 物語文学が, 女性の手によってなされ, 
『枕草子』はその一方を代表するものといっていい。

定子は，中の関白藤原道隆の娘である。この時代は， 藤原鎌足の子の不比等の子達によって分れた，藤原 4 家 の内の北家の全盛時代であり，この一族は，政治の実権 を握る摄政関白を独占していた。つまり，作者清少納言 は，位を究めた一族の娘の華やかな後宮に仕えていたわ けで，その筆の走りにも，この世の頂上にいるという自 信と高慢が表われている。

しかし，道隆が関白でいるうちはよかったが，没して からは, 時の権力がすっかり, 道隆の弟に当たる, 御堂 関白藤原道長のほうに移ったため, 道長方と折り合いの 覀かった定子の兄弟たちは皆落ちぶれ, 定子も落飾し, 清少納言の晚年も不幸であったと伝えられている。その 道長の娘で, やはり一条天皇の中宮であった彰子に仕え ていたのが，紫式部であり，その『紫式部日記』の中に， 清少納言のことを記した有名な一節がある。

「清少納言こそ，したり顔にいみじう侍りける人。さばかり さかしだち，真字かきちらして侍るほども，よく見れば，ま だいとたへぬことおほかり。かく，人にことならむと思ひこ のめる人は, かならず見劣りし, 行くす芧うたてのみ侍れば, 體になりぬる人は，いとすごうすずろなる折も，もののあは れにすすみ，をかしきことも見すぐさぬはどに，おのづから， さるまじくあだなるさまにもなるに侍るべし。そのあだにな りぬる人のはて，いかでかはよく侍らむ。」

と，かなり手笅しい評であるが，確かに「枕草子』には， ややともすればうんざりするほど，自己の才気を人に哀 められた話，また中宮定子の美しさ雅やかさを自慢する 話が多く現われる。そこにはこういう世界で姩を競い， 才を競う女性特有の，見栄と虚栄が顔をのぞかせている ともいえる。

伝本には多種あり，詳述は省くが，本研究に使うもの は 300 近い段に分かれ，その後に「一本」とされるもの が続く。格段は，「家は」「市は」「すさまじきもの」な ビで始まり，その下にそれに続くものを列挙する形の「類 集」, 自然や人生に関する感想を記す「随想」, 中宮定子 を中心とした宮廷生活の日記「回想」に分けられるが， 中でも「類集」は『枕草子』の特色をもっともよく表わ すもので，ものごとの断定的評価を成す部分である。

\section{2. 研究の方法}

まず建築空間を表わす用語を抽出するが，和歌文学の 場合とは性格が異なるところから，次のように，建築要 素と文脈要素の二軸によって分類し集計する。

建築要素とは, 建築空間を, 建築, 部屋, 部位, 部材・ 建具, 家具, 庭, その他, と分類したもので,ここでは 直接的な建築に限定せす，庭の自然や，車なども，幅広 く抽出の範囲としている。文脈要素とは, その用語が, 一般名, 場所名, 人名, 機関名を指す場合によって分け, 更に一般名, 場所名の場合はそれが, 行為の舞台か, 行 為の対象か，美的対象かによって分類したものである。
以下に，その解説と用語例を示す。

$<$ 建築要素〉

イ：建物建物全体, 棟（家, 屋, 里など)

口：部屋部屋, 建物の空間的な部分（局, 縁，渡殿など)

八：部位 建物の物質的な部分 (軒, 空なと)

二：部材 - 建具 部材 - 部屋の仕切り（柱, 策, 格 子など)

木：家具家具, 公内調度類（几帳, 火桶子 ご)

へ：庭庭全体, 庭の構成物（庭, 池, 花 なよ゙)

ト：その他生活空間を表す語で上記に含まれ ないもの(車, 都など)

〈文脈要素 $>$

A：一般名建築の一般的な名称 (家, 縁, 簡 など)

$\mathrm{B}$ ：場所名 固有の建築を表わすものの中で場 所, 建物を意味する名称（職の御 曹司，殿上など)

C：人名建築を表わす語の中で人を指す名 称（殿, 左京の君など)

D：機関名建築を表わす語の中で組織，団体 を指す名称（主殿司，瀧口など）

一般名・場所名の文脈による分類

$\mathrm{a}$ : 行為の舞台＼cjkstart行為が行われている所及びその背 景となっている場合

$\mathrm{b}$ : 行為の対象＼cjkstart建築を指す語に対して行為が行わ れている場合

$c$ : 美的対象美的な言葉に修飾されたり,修飾 したりする場合。また和歌に詠ま れた場合

本研究における建築用語の抽出は，一般的な三巻本の 岩瀬文庫のものを底本としている，岩波書店・日本古與 文学大系・『枕草子 紫式部日記』。及び，やはり三 巻本の陽明文庫のものを底本とした，新潮社・新潮日本 古典集成・枕草子』(上・下 $)^{2), 3}$ に上り, 本文中の引 用は全て後者によった。

建築学の分野における古典文学を資料とする既往の研 究としては，木村徳国『上代語にもとづく日本建築史の 研究出)がある。これは『古事記・日本書紀・万葉集』 を資料として, 日本古代の建築用語（家, やどなど全作 を表す語に限る) の意味について研究するものである。 また，小野恭平『中古の文学作品からみた山里の基本的 イメージとその美について」ゔは「山里」の諧に限つ て考察している。「源氏物語」に関して,太田静六氏 ${ }^{6)}$, 池浩三氏

『枕草子」の建築空間を系統的に抽出し研究したものは, 
表一1 全編における分類別頻度

\begin{tabular}{|c|c|c|c|c|c|c|c|c|c|}
\hline & \multicolumn{4}{|c|}{ 丈 } & \multicolumn{3}{|l|}{ 事 } & \multirow[b]{4}{*}{ It } \\
\hline & & \multicolumn{4}{|c|}{ 进萧用 } & \multirow{2}{*}{\multicolumn{3}{|c|}{ 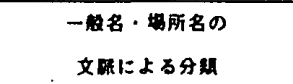 }} & \\
\hline & & \multicolumn{2}{|c|}{ 物を植す比 } & \multicolumn{2}{|c|}{ 人を栺す姑 } & & & & \\
\hline & & 一般名 & 所名 & 人名 & 的名 & 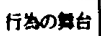 & 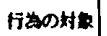 & 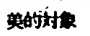 & \\
\hline \multirow{6}{*}{ a } & e & 211 & 194 & 188 & 29. & 200 & 107 & 82 & 622 \\
\hline & 物 & (11.9) & $(11.0)$ & (10.7) & (1.6) & (11.7) & (6.1) & (5.2) & (35.3) \\
\hline & 期 & 148 & 48 & 1 & & 130 & 58 & 6 & 195 \\
\hline & 国 & (8.3) & (2.7) & $(0.1)$ & & (7.1) & (3.3) & $(0.3)$ & $(11: 1)$ \\
\hline & 正 & 18 & & & & 12 & 3 & 4 & 19 \\
\hline & 位 & (1.1) & & & & $(0.7)$ & $(0.2)$ & $(0.2)$ & $(1: 1)$ \\
\hline \multirow{4}{*}{ 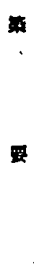 } & 罚 & 152 & 1 & & & 58 & 89 & 8 & 153 \\
\hline & 墨 & (8.6) & $(0.1)$ & & & (3.3) & (5.1) & $(0.3)$ & (8.7) \\
\hline & 家 & 186 & 2 & & 2 & 42 & 120 & 36 & 200 \\
\hline & 周 & (11.1) & $(0.1)$ & & $(0.1)$ & (2.4) & (6.8) & $(2,0)$ & (11.4) \\
\hline \multirow{2}{*}{ 萂 } & a & $\begin{array}{l}419 \\
(23.8)\end{array}$ & & & 2 & 74 & 113 & 232 & 421 \\
\hline & $\begin{array}{l}7 \\
\vdots \\
9 \\
\text { 他 }\end{array}$ & $\begin{array}{l}125 \\
(7.1)\end{array}$ & $\begin{array}{r}21 \\
(1.2)\end{array}$ & $\begin{array}{c}4 \\
(0.2)\end{array}$ & & $\begin{array}{r}32 \\
(1.8)\end{array}$ & $\begin{array}{r}84 \\
(4.8)\end{array}$ & $\begin{array}{r}30 \\
(1.1)\end{array}$ & $\begin{array}{l}150 \\
(8.5)\end{array}$ \\
\hline & It & $\begin{array}{c}1288 \\
(72.0)\end{array}$ & $\begin{array}{l}268 \\
(15.1)\end{array}$ & $\begin{array}{l}183 \\
(11.0)\end{array}$ & $\begin{array}{r}33 \\
(1.9)\end{array}$ & $\begin{array}{l}554 \\
(31.5)\end{array}$ & $\begin{array}{l}674 \\
(32.6)\end{array}$ & $\begin{array}{l}408 \\
(23.1)\end{array}$ & 1780 \\
\hline
\end{tabular}

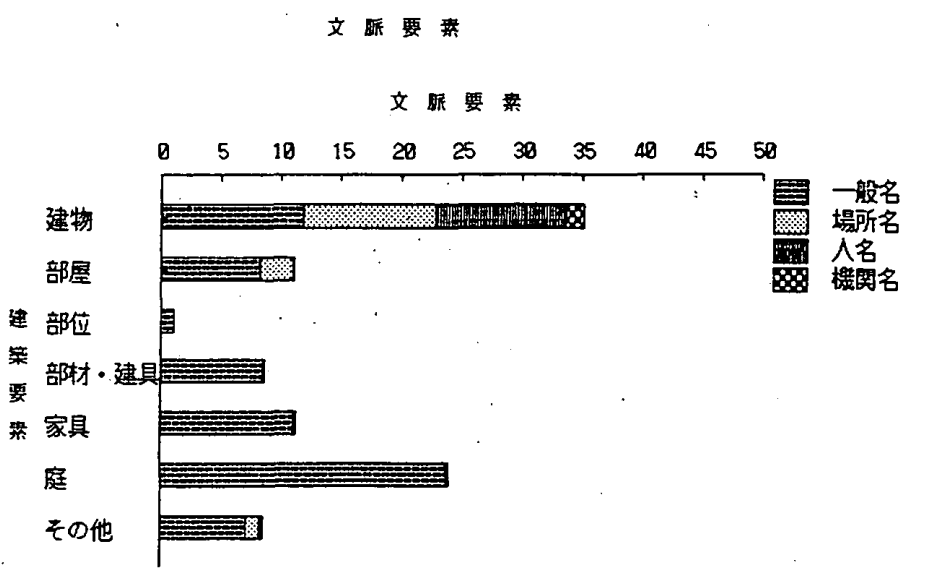

図一1 全編における建築要素別の建築用語の比較

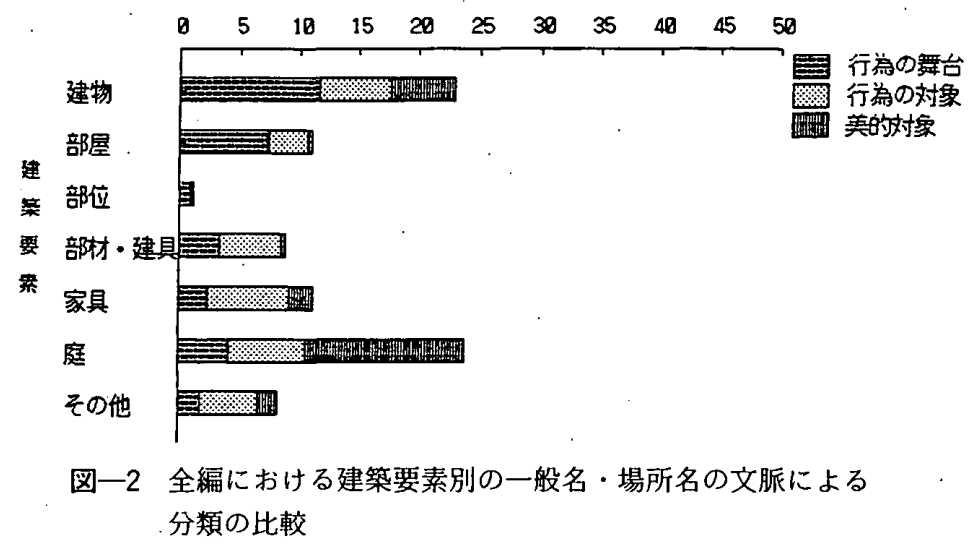

国文学の分野にも見当たらない。

3.【枕草子」における建築空間を表す用語 の概要

建築用語の，この二軸による分野別頻度が 表一1であり, 頻度の多い用語を挙げたのが 表一 2 であり, 各分類ごとの多頻度用語が表 -3である。これをグラフ化したものが図一 1，図一2である。

まず注目されるのが,「御車, 車」の多い ことである。後宮の女性がでかけるときには， 車が欠かせない乗り物となっており，車に関 する趣味のよしあしを論じた部分が多いこと を示している。次に多いのが，「宮」「殿」な どの用語であるが，これはほとんどが人物を 表わしている。また「御策・策」「御几帳・ 几帳」「御㘶風・屏風」など建築内部の建具, 家具が多いのが、门葉集』8 などと大いに異 なる点である。美的対象としてはやはり，「庭」 が多く，その評価意識は「花」に集中してい る。

\section{4. 劇場都市としての宮廷}

「万葉集』において多く見られた「宮」や「殿」 はここでは人物を指すようになっており，時 代の変化が感じられるが,「宮」はたいてい は中宮定子,「殿」は多く関白道隆を指して いる。貴人を指すのに建築空間を用いるのは, この時代には当たり前となっており，「源氏 物語」にもこの傾向が強く，そのためにわれ われにはそれが誰を指すのか分かりにくく なってもいる。位の高い人物の名を直接口に 出すのははばかられるという，日本的な感性 によるものであろう。

吅葉集」の建築空間が, 外部, それも「遠 望の空間 $]^{81}$ に偏っていたのに対して,ここ では，建築の内部空間が圧倒的である。「車」 が多いというのも，それは言ってみれば「移 動する内部空間」であることを意味している。 『枕草子」はほとんゼが, 宮廷内部の, 人物 の振る舞いを描いている。人物とは天皇, 中 宮, 関白, その他の公達, 女官, 僧などで, その振る舞いをほめたりけなしたりしている のである。「なによりも人のふるまひ，心の よしあしのたたずまひを教へたるものなり」 という教養書的な受け取り方”もあるようだ が, 私は, これは全く個人的な, 趣味的美学 の書であると考える。そこに登場する人物は， あたかも舞台のうえで演技する役者のよう に，その日常の立ち振る舞いを審美されてい 
表一2 全編における建築用語の頻度順

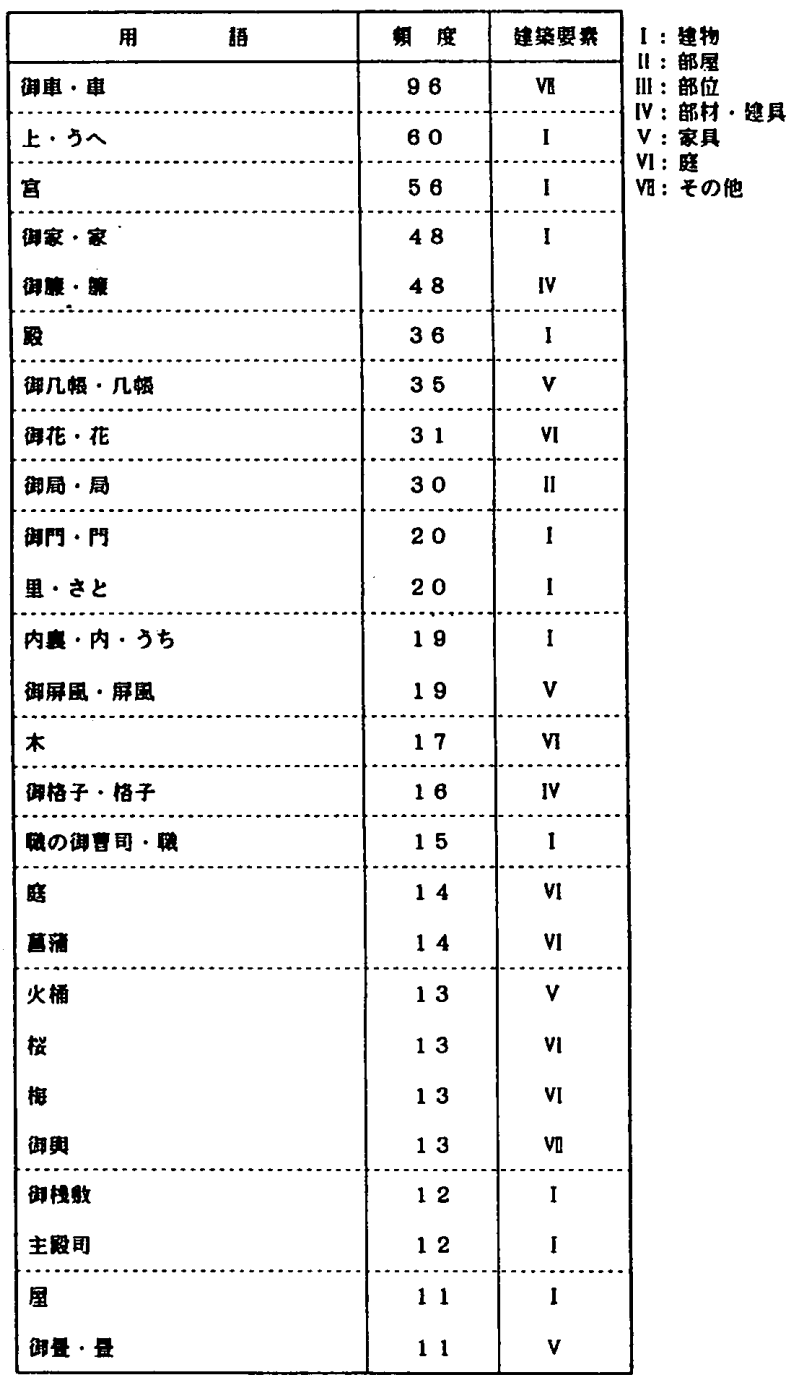

表一3 全編における頻度の高い用語

\begin{tabular}{|c|c|c|c|c|c|c|c|}
\hline & -8 & 所 8 & ᄉ & 田 & F⿻川的 & F⿻大力八 & 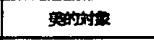 \\
\hline ? & 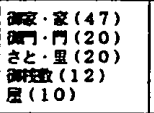 & 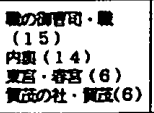 & 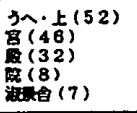 & 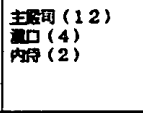 & 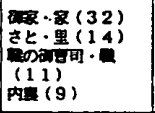 & 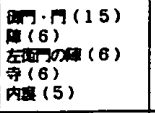 & 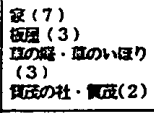 \\
\hline E & 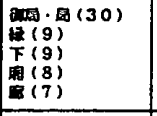 & 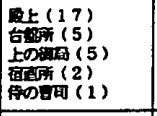 & 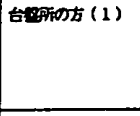 & & 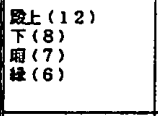 & 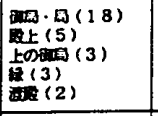 & 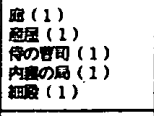 \\
\hline (1) & 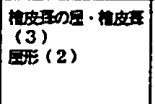 & & & & En & \begin{tabular}{|l}
$\operatorname{ctg}(1)$ \\
(1) \\
(1) \\
(1)
\end{tabular} & 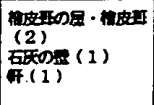 \\
\hline 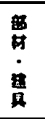 & 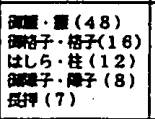 & & & & 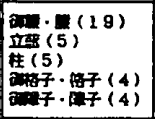 & 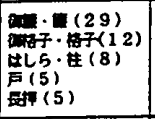 & 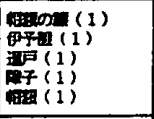 \\
\hline A & 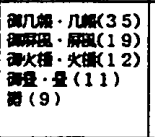 & 敌(1) & & (20) & 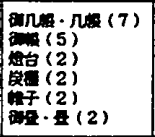 & 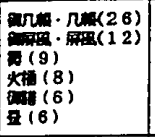 & 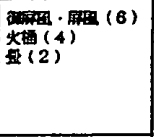 \\
\hline 田 & 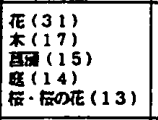 & & & 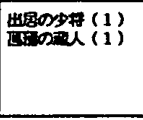 & 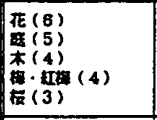 & 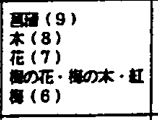 & 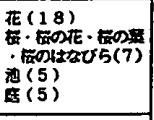 \\
\hline 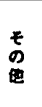 & 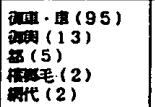 & $\begin{array}{l}\text { 要少京 (2) } \\
\text { (2) }\end{array}$ & 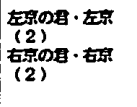 & & 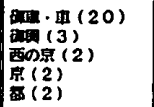 & 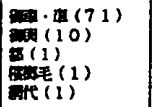 & 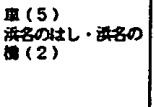 \\
\hline
\end{tabular}

るのである。これは，宮廷という劇場における，人間の 交遊の様を，あたかも劇を見るように描いているのであ り，一つ一つの建築空間はその舞台となっている。この 時代の宮廷は，人と人との演技の相互鑑賞の場であり， その演技の場面に, 儀式があり, 祭りがあり, 季節の行 事があり，花鳥風月という文化があったのである。多く の棟が渡り廊下でつながったこの時代の寝殿造りは, 一 つの街のような空間の複層性を持ち, 特に, 内裏という， 閉ざされた巨大な建築の複合世界は，様々な種類の殿上 人たちが交遊する一つの都市空間といってもよいような ものであった。

劇場では「観る」ということが重要である。『枕草子』 においても人が人を観る，人が花鳥風月を観るという場 面が極めて多く，その観たさまが，美しく，立派で，閏 情があるというのが「をかし」という評価になるので放 る。その観るため，あるいは隠すための道具立てが「御 筆・策」「御几帳・几帳」「御屏風・屏風」「御障子・障子」 であり、こういった視線を調節する建具, 家具が，この 劇場ではちょうど舞台の「幕」の役割を果しているのて ある。

「20段」「清凉殿の丑寅の角の, 北のへだてなる御障子は, 荒海の絵。生きたるものどものおそろしげなる，手長・足骎 などをぞ描きたる。上の御局の戸をおしあげたれば,つねに 目に見ゆるを，憎みなどして，笑ふ。

高欄のもとに，青き㼛の大きなるを据㤩て，桜のいみじう おもしろき枝の, 五尺ばかりなるをいと多く插したれば, 高 欄の外まで咲きこぼれたる昼つ方，大納言殿，桜の直衣のす こしなよらかなるに，濃き紫の固文の指貫，白き御衣ども， うへには湦き綾のいとあざやかなるを出だしてまるりたまへ るに，主上のこなたにおはしませば，戸口の前なる細き板教 にるたまひて，ものなど申したまふ。

御策のうちに，女房，桜の唐衣どもくつろかに脱き重れて，
藤・山吹など, いろいろ好ましう てあまた，小半部の御簾よりも斿 し出でたるほど，昼の御座のかた には，御瞨まるる足音たかし。垍 跬など『おーしー」といふ声きこ ゆるも，うらうらとのどかなる日 のけしきなど，いみじうをかしき に，はての御盤とりたる蔵人まるる りて, 御膡奏すれば, 中の戸より わたらせたまふ。御供に，廂より 大納言殿，御送りにまるりたまひ て, ありつる花のもとに帰りるた まへり。

宮の御前の, 御几帳おしやりて, 長押のもとに出でさせたまへるな どなにとなくただめでたきを， さぶらふ人も思ふことなき心ちす るに，『月も日もかはりゆけどもう さにふる三室の山の』といふ言を， いとゆるらかにうち出だしたまへ る、いとをかしうおぼゆるにぞ、げ 
に，千年もあらまほしき御ありさまなるや。」

「うへ」は一条天皇，「宮」は中宮定子，大納言は定子の 兄伊周を指している。これは天皇, 中宮, 大納言が，あ る笁間に登場するさまを描写して，その美しさをたたえ ている部分である。その道具だてに極めて多くの建築の 部分, 御障子, 戸, 勾欄, 戸口; 板敷, 御策, 廂, 御几 帳, 長押, などが使われており，そういった舞台道具と ともに登場する人物の,振る舞いの見事さが,「なよらか」 「あざやか」「をかし」「めでだきなどの言葉で表現さ れている。

「99段」「夜半ばかりにわたらせたまひしかば, いくばくも あらで, 明けぬ。登花殿の, 東の廂の二間に, 御しつらひは したり。宵にわたらせたまひて，またの日はおはしますべけ れば，女房は，御曼宿に向かひたる渡殿に，さぶらふべし。

殿・上，暁に，一つ御車にてまるりたまひにけり。早朝， いと疾く御格子まるりわたして，宮は，御曹司の南に，四尺 の屏風，西東に御座敷きて，北向きに立てて，御畳の上に御 茵ばかり置きて, 御火桶まるれり。御屏風の南, 御帳の前に, 女房いと多くさぶらふ。」

「御曼のをりになりて, 御理髪まるりて, 蔵人ども, 御䧄曼 の髪上げて進らするほどは，隔てたりつる御椐風もおしあけ つれば，垣間見の人，隠れ蓑とられたる心ちして，飽かずわ びしければ, 御策と几帳との中にて, 柱の外よりぞ, 見立て まつる。衣の裾・裳などは, 御策の外にみなおし出だされた れば, 殿, 端の方より御覧じ出だして,「あれは, 誰ぞや。 かの御筑の間より見ゆるは」と, 各めさせたまふに，「少納 言が,ものゆかしがりて，はべるならむ」と申させたまへば, 「あな, 恥づかし。かれは，古き得意を。门と憎さげなる娘 ども持たり」ともこそ, 見はべれ」などのたまふ御気色，い としたり顔なり。」

これは淑景舎（桐䣽）に住む，東宮の妃となる関白道隆 の娘, つまり定子の妹が来るのでその様子を見ようとい う話で, 淑景舎, 中宮定子, 関白道隆, および清少納言 本人の姿が描かれている。ここでは, 廂, 屏風, 篻, 几 帳, 畳; 格子, 障子, 柱, などとともに, 登場人物の衣 装がよく描かれており，女性らしく実にこまやかな観察 眼が発揮されている。

外出時必ず車に乗る宮廷女性にとって，車もまた重要 な「観る，あるいは観られる」ための舞台であった。

「94段」「卯の花の，いみじう咲きたるを折りて，車の篻． 側などに插しあまりて，留ひ・棟などに長き枝を，咠きたる やうに插したれば，ただ，卯の花の垣根を，牛にかけたる とぞ見ゆる。供なる郎等もいみじう笑ひつつ,ここまだしこ こまだしと插しあへり。」

「220段」「万づのことよりも，わびしげなる車に，装束わる くて物見る人, いともどかし。説経などは, いとよし。罪う しなふことなれば…赤れだになほ，穴がちなるさまにては 見苦しきに，まして，祭などは，見でありぬべし。下䈨なく て, 白き単衣の袖などうち垂れてあめりかし。ただ,その日 の料と思ひて，車の策も仕立てて，「いと口惜しうはあらじ」 と, 出でたるに, まさる車など見つけては, 「何しに」とお ぼゆるものを‥ままいて，いかばかりなる心にて，さて見る らむ。
などに,車をめぐる女性の見栄と虚栄がよく表れている。 あたかも現代のマイカー時代をほうふつとさせるような 状況がこの時代にもあったのだと思われて興味深い。

車の種類については次のような感想を述べている。

「29段」「檳榔毛は，のどかにやりたる。急ぎたるは，わる $<$ 見ゆ。

網代は，走らせたる。人の門の前などよりわたりたるを， ふと見やるほどもなく過ぎて，供の人ばかり走るを，「誰な らむ」と思ふこそ;をかしけれ。ゆるゆると久しくゆくは， いとわろし。」

「一本」の「22」にも同様の記述がある。つまり檳榔毛 の車は造りも手の込んだ高級車であるから，ゆっくりと 走るのがよく，あまりせかせかとしているのは品がない が, 網代の車は機能を重視した軽快な造りであるから, 走るという機能を十分に発揮するのがいいのだという, 形態と機能の組み合わせの美を評価しているのが面白 い。

\section{5. 趣味の良さの原典一空間美学}

先に述べたように，『枕草子』はあらゆる生活様態の 美学的評価の書であり, 日本的趣味の良さの原典のよう なものであるが，その評価の対象は，人間の振る舞い， その衣装, 自然の草花などとともに, 建築空間にも及ん でいる。その内容を考察すると, 各段の建築空間評価の 仕方には次のようなタイプがある。

A：直接的な評価一个類集」における，ものづくしの ように，はっきりと断定的にもののよしあしを決 めつけているもの

$\mathrm{B}$ ：間接的な評価一人物の振る舞いの評価, 行事や季 節の評価に絡んで，その周辺の建築空間が間接的 に評価されるもの

C：一般的な記述一単にある情景を説明する中に, 微 細な評価が感じられるもの

先に上げた，天皇や定子，関白，淑景舎などの振る舞い を評価する中に表れるものは (B) に当たるのであるが, ここでは特に (A) の直接的評価を考察することによっ て，『枕草子』の美学の性質を明らかにしようと考える。

「25段」「忍びで来る人見知りて，吠ゆる犬。

あながちなるところに隠し伏せたる人の，質市たる。また， 忍び来るところに，長烏帽子して，さすがに「人に見えじ」 と，まどひ入るほどに，物につきさはりて，「そよろ」とい はせたる。伊予策などかけたるに,うちかづきて、「さらさら」， と鳴らしたるも, 认とにくし。帽額の䈨はまして, 小端のう ちおかるる音, いとしるし。それも, やをら引き上げて入る は, さらに鳴らず。遗り戸をあらく閉て開くるも, いとあや し。すこしもたぐるやうにして開くるは, 鳴りやはする。あ しう開くれば; 障子なども, ごほめかしうほとめくこそしる けれ。」

人目をしのんでくる，という状況のときに，策や遣り戸， 障子などの音を立てるのは大変困る, ということで, 後 に続く「開けて出で入るところ,閉てぬ人, いとにくし。」 
とともに，建具の扱いを評価している。

「57 段」「よき家の，中門あけて，檳榔毛の車の白く清げな るに、蘇枋の下篻，にほひいときよらにて，榻にうちかけた るこそ,めでたけれ。」

家と車の好ましいコンビネーションを評価している。

「84 段」「なまめかしきもの。ほそやかにきよげなる君達の， 直衣姿。をかしげなる童女の，表の袷などわざとはあらで， ほころびがちなる汗衫ばかり着て, 卯桘・薬玉など長くつけ て，高欄のもとなどに，扇さしかくしてるたる。

薄様の冊子。柳の萌え出でたるに，青き薄様に書きたる文 つけたる。三重がさ称の扇。五重はあまり厚くなりて，もと など憎げなり。

いと新しからず，いたうもの旧りぬ檜皮葺きの屋に，長き

菖蒲をうるはしう苜きわたしたる。

青やかなる筑のしたより，几帳の朽木形いとつややかにて， 紐の吹きなびかされたる，いとをかし。

白き組の, 細き。

帽額あざやかなる篻の外，高橍に，いとをかしげなる猫の， 赤き頸網に白き札つきて, 鎖の緒, 組の長きなよ゙つけて, 曳 きありくも，をかしうなまめきたり。」

「なまめかしい」とは優美という程度の表現, 少し古び た檜皮咠きの屋根にしょうぶをきちんと苜き渡してい る, 青々とした御策, 几帳の帷子の色鮮やかなもの, そ の紐が風になびいている様，簾と猫の様子の組み合わせ をほめたたえる。

「124段」「九月ばかり，夜一夜降り明かしつる雨の，今朝は やみて，朝日いとけざやかに射し出でたるに，前栽の露は，

滾るばかり濡れかかりたるも，いとをかし。透垣の羅文・軒 の上などは，蛋くいたる蝴蛛の巣の毀れ残りたるに雨のかか りたるが，白き玉をつらぬきたるやうなるこそ，いみじうあ はれに，をかしけれ。」

九月の雨夜の後の朝日が鮮やかな中に，透垣，軒のあわ れな風情を楽しんでいる。季節を限定し, 朝日, 露, 蜘 蛛の巣, 雨の白い玉などと一体となった「あはれ」の美 学を明らかにしている。

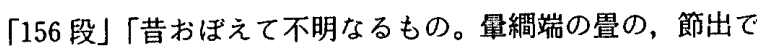
来たる。唐絵の屏風の, 黒み, 面そこなはれたる。絵師の, 目暗き。七，八尺の㹂の，赤くなりたる。葡萄染の織物の， 灰かへりたる。色好みの, 老いくずほれたる。おもしろき家 の，木立焼け失せたる。池などは，さながらあれど，浮草・ 水草など, 茂りて…」

昔はよかったが今はだめなものは, 上等の畳, 唐絵の古 くなったもの，いい家の木立の焼けてしまったもの，亡 いうわけで，やや否定的な評価だが，ここにも「あはれ の美学」が見え隠れしないでもない。

「170段」「六位蔵人などは，思ひかくべきことにもあらず。 冠得て, 何の権守・大夫などいふ人の, 板屋などの狭き家持 たりて，また，小檜坦などいふもの新しくして，車宿にに車 ひき立て, 前近く一尺ばかりなる木生ほして, 牛つなぎて草 など飼はするこそ，いと憎けれ。

庭いと清げに掃き，紫革して伊予策懸けわたし，布障子張 らせて，住まひたる，夜は，門つよく鎖せ」など、言おこ なひたる，いみじう生ひ先なう，心づきなし。

親の家・舅はさらなり，叔父・兄などの，住まぬ家，その
さべき人なからむは，おのづからむつまじくうち知りたらむ 受領の，国へいきていたづらならむ，さらずば，院・宮ばら の, 屋あまたあるに, 住みなどして, 官待ち出でて後, いつ しかよきところ尋权取りて，住みたるこそよけれ。」

現職を去った人が,小さな家をこぎれいにしているのは, 先もないと思われてよいものではない, ということで,

少納言の生活の美学はなかなか手厳しい。

「171 段」「女ひとり住むところは，いたくあばれて，築土な ビも全からす，池などあるところも，水草る，庭なだも，潇 に茂りなどこそせ柿も，ところよ゙ころ，砂の中より青き㐨 うち見え，淋しげなるこそ，あはれなれ。

ものかしこげに，なだらかに修理して，門いたく固め，き はぎはしきは，いとうたてこそおぼゆれ。」 女の一人住まいは，土塀も崩れがちで，庭も寂しげなほ うがよい，よく修理し，門も厳重にしているの沈よくな いという，現代の感覚ではやや奇異な印象も受ける美的 評価である。女の一人住いを「あはれ」とむすびつける， 興味深い意見である。

「188段」「野分のまたの日こそ，いみじうあはれに，をかし けれ。

立蔀・透坦などの乱れたるに,前栽どもいと心苦しげなり。 大きなる木どもも倒れ，枝など吹き折られたるが，萩・女郎 花などの上に，横ろばひ伏せる，いと思はずなり。格子の頭 などに，木の葉をことさらにしたらむやうに，こまごまと吹 き入れたるこそ，荒かりつる風のしわざとはおばえね。」

風の後の, 庭などが乱れているのも，心にしみるものだ， という評価である。

「216段」「大きにて，よきもの。家。餌袋。ほうし。果物。 牛。松の木。唲の墨。」

大きいほうがいいものの中に家も入っているわけだが, 他のものとの並列が面白い。

「218段」「人の家につきづきしきもの。暨折りたる郎。円坐。 三尺の几帳。大きやかなる童女。よき半物。侍の雑仕。折教 く。懸盤。中の盤。おはらき。衝立障子。摫き板。装束よく したる慨袋。唐傘。棚廚子。提子。銚子。」

家にはこういうものがあったほうがいいということ。

「233段」「雪は, 檜皮莫, いとめでたし。すこし消えがたに なりたるほよ゙。まだいと多うも降らぬが，瓦の目毎に入りて， 黒う丸に見えたる，いとをかし。時雨・霜は，板屋。霜も，

板屋, 庭。」

天候と屋根の組み合わせの美学である。雪は檜皮苦, 瓦 茟がよく, 時雨, 霞, 霜は板屋がいいという。まさにそ のとうりで，鋭い感覚といわざるをえない。

「238段」「騒がしきもの。走り火。板屋の上にて, 鳥の, 斎 の生飯食ふ。」

これも面白い。同じ板屋の音でも時雨はいいが，烏はう るさいという。

「259段」「また, 高麗端の席青うこまやかに厚きが, 縁の文 いとあざやかに黒う白う見えたるを，ひき展げて見れば、「な にか,なほこの世は，さらにさらに得思ひ捨つまし」と，命 さえ惜しくなむなる」

青くて編み目が細く厚みのある畳の縁の模様の美しさ に，命も惜しいというほどの感激をしている。感性の鋭 
い女性ゆえのことだろう。

「一本」のうち

「5」「下の心, 構へてわろくて, 清げに見ゆるもの。唐絵の

屏風。石灰の壁。盛物。檜皮直きの屋の上。河尻の遊女。」

内側は悪くて表面だけよく見えるものの意。

「13」「硯の管は, 重ねの, 蒔絵に雲鳥の文。」

「17」「櫛の管は，蛮絵，いとよし。」

「18」「鏡は, 八寸五分。」

「20」「火桶は，赤色。青色。白きに造り絵も，よし。」

「21」「畳は，高麗端。また，黄なる地の端。」

家具調度，それぞれの好みを述べる。

以上のような空間評価の特徵としては, 建築空間その ものを美しいとか, 醜いとかいうのではなく，空間にま つわる「風情」に焦点が当てられていることである。空 間にかかわる「をかし」という評価はあくまで, 人, 季 節，雪や時雨などの天候，との関係に置いてなされるの であって，空間そのものをいう場合は極めて少ない。こ こに取り上げた「直接的な評価」の部分においてもそう なのであり，人の振る舞いや，季節の行事の脇役として の「間接的評価」においてはなおさらそうである。

つまりこの美学は, 風情の美学であり, 状洗の美学で ある。もちろん著者が女性であるということにもよろう が，これはある意味で，日本文化の特質と，また日本建 築の物理的な特質ともかかわっていると思われる。

清少納言の空間趣味の特質としては，やはり「優美な もの」「清らかなもの」「華やいだもの」などに評価が置 かれているが，女性らしく「細かいもの」「風にたなび く弱々しいもの」などに特徴が見られる。また面白いの は,「古錆びたもの」「荒れ果てたもの」「崩れかけたもの」 などを美的に評価している点で，現代の感覚とはかなり 異なった「あはれ」の美学を感じるところである。特に 関白道隆が亡くなって定子の後宮に勢いのなくなった後 半の段に，そういった「あはれ」の趣味が目立っている ようだ。『枕草子」は基本的には，社会の頂点にある文 化サロンを描いた華やかな空間性の書であるが，そこに も少しづつ，物寂しい「あはれ」の空間美学が顔を出し てくるのである。

\section{結・『枕草子」の建築空間}

以上のような分析の結果として, 目枕草子」の建築空 間は次のようにまとめられる。

（1）劇場都市としての宮廷

『枕草子』は平安王朝における後宮の生活を事細かに 描写し，評価した書であるが，そこには渡殿でつながっ た，複合的な建築としての寝殿造りの空間が，あたかも 一つの都市のように描かれており，そこに現れる殿上人 の生活は，その都市空間の中の文化サロンにおける，お 互いの振る舞いを鑑賞し，評価しあうという，演劇的な ものである。『枕草子」における宮廷空間は劇場都市之 もいえるようなものであった。
またここでは,『万葉集」のような和歌文学と比べると， 建築の内部空間が任倒的に優勢である。

（2）舞台装置としての建具, 家具, 車

宮廷文化サロンの舞台には様々な装置, 道具が登場す るが, 中でも重要なのが, 格子, 障子, 策, 几帳, 屏風, などの建具, 家具で,これらは人の視線を隔て, 調整す る舞台装置として，なくてはならないものであった。ま た車もここでは動く舞台として扱われている。『枕草子」 に登場する建築空間はこれらがほとんどといってよい。

（3）風情と状況の美学

『枕草子」は劇場的な空間における生活様態の美的評 価の書であるが，その評価の仕方は，極めて私的で趣味 的であり, また空間そのものの構造ではなく, ある状況 における風情を評価するのであり，風情と状況の美学と いうべきものである。

（4）「をかし」から「あはれ」へ

清少納言の建築空間評価の基本は,「華やか」「清らか」 「細い」「柔らかい」など，いかにも女性的なものであり， そこに，人の振る舞い，季節の自然，行事などが調和し たときに「をかし」という評価を与えているのであるが， そこに少しづつ，「錆びれた」「物寂しい」つまり「あは れ」というべき空間の評価が加わってくる。

\section{謝 辞}

本研究を行うにあたりご協力頂いた, 当時研究室の学 生であった，長尾環美さんに，深謝の意を表します。

\section{参考文献}

1) 池田急鑑ほか 2 名：日本古典文学大系 $19 \cdot$ 枕草子・紫式 部日記，岩波書店，1958.9，pp. 27-28「斯波義将の竹馬 抄には…教養書としてうけとっている。」よる。

2）萩谷 朴：新潮日本古典集成・枕草子上，新潮社，昭和 52.4

3）萩谷 朴：新潮日本古典集成・枕草子下，新潮社，昭和 52.5

4）木村徳国：上代語にもとづく日本建築史の研究，中央公 論美術出版, 昭和 63.2

5）小野恭平：中古の文学作品からみた山里の基本的イメ一 ジとその美について：日本建築学会計画系論文報告集, 第 393 号, pp. $72-81$

6）太田静六：寝殿造の研究，吉川弘文館，昭和 54

7）池 浩三：源氏物語一その住まいの世界, 中部建築ジャー ナル, 1987.5-1987.11

8）若山 滋ほか 1 名：「万葉集」における建築空間：日本建 築学会計画系論文報告集，第 388 号, pp. 116-123, 1988. 6 による

9）大野 晋ほか 2 名：岩波古語辞典, 岩波書店, 1974.12

10）池田驅鑑：平安朝の生活と文学，角川文庫，昭和 39

11）前 久夫：文学の舞台一住まい, 東京美術, 昭和 61.1

12）市古貞次ほか 9 名：日本古典文学大辞典一簡約版，岩波 書店, 1986.12

(1989 年 5 月 10 日原稿受理, 1990 年 2 月 26 日採用決定) 